\title{
Nutritional value of meat: the influence of nutrition and physical activity on vitamin B12 concentrations in ruminant tissues
}

\author{
Isabelle ORTIGUES-MARTYa*, Didier MICOL ${ }^{\mathrm{a}}$, Sophie PRACHE ${ }^{\mathrm{a}}$, \\ Dominique DOZIAS ${ }^{\mathrm{b}}$, Christiane L. GIRARD ${ }^{\mathrm{c}}$ \\ a Unité de Recherches sur les Herbivores, INRA, Theix, 63122 Saint-Genès-Champanelle, France \\ b Domaine Expérimental INRA du Pin au Haras, 61310 Le Pin-au-Haras, France \\ c Centre de Recherche et de Développement sur le Bovin Laitier et le Porc, \\ Agriculture et Agroalimentaire Canada, 2000 route 108 Est, CP 90, Lennoxville, Québec, Canada
}

(Received 13 January 2005; accepted 23 March 2005)

\begin{abstract}
An important nutritional characteristic of ruminant meat is its high content in vitamin B12. The variability of these contents is not known. Three studies were been set up in order to test the influence of the animal species ( 2 studies on Charolais steers slaughtered at 30-32 months of age, $n=24$ and $n=30$ and a third one on lambs slaughtered at 4.5 months of age, $n=21$ ), of the nature of the diet (grass vs. maize silage, lucerne or concentrate diets) and of physical activity (without or with walking) on the vitamin B12 contents of different muscle types (rather oxidative (Rectus Abdominis, RA), intermediate (Longissimus Dorsi, LD), or glycolytic (Semi Tendinosus, ST)) and on the liver. The animals were supplemented in macro and trace minerals according to usual feeding practices in France in order to theoretically avoid any risk of deficiency. For this reason, cobalt allowances, which are necessary for the ruminal synthesis of vitamin B12, could differ among treatments. The results indicate the following: (1) cobalt allowances varied widely among treatments, from (sub-)deficient to plethoric allowances, influencing vitamin B12 contents of the liver, and muscles (only in case of deficiency), (2) the effects of dietary treatments or of physical exercise were essentially related to differences in cobalt allowances, (3) the oxidative type muscle $(R A)$ showed contents which were double those in glycolytic type muscle (RA 10.8 vs. $\left.S T 5.0 \mathrm{ng} \cdot \mathrm{g}^{-1}\right)$ and (4) vitamin B12 contents of raw muscles were lower than the values indicated in tables of feed composition for humans for cooked meat ( 0.5 to 1 vs. 2 to $\left.3 \mu \mathrm{g} \cdot 100 \mathrm{~g}^{-1}\right)$.
\end{abstract}

meat / ruminant / muscle / liver / vitamin B12 / nutritional value / nutrition

\section{INTRODUCTION}

An important nutritional characteristic of meat from ruminant animals is its high content in vitamins of the B group, in par- ticular vitamin B12 [1]. The latter is strictly synthesised by microorganisms and enters the human food chain either by contact of the food with microorganisms or by incorporation of some microbial constituents

* Corresponding author: ortigues@clermont.inra.fr 
into foods. In Ruminants, vitamin B12 is synthesised within the rumen and absorbed through the digestive tract [2] before being transported via the blood to body tissues, first the liver and subsequently the muscles [3]. Ruminant products (meat and milk) constitute the major natural source of vitamin B12 for humans [4]. Ruminant meat intake may cover an important part of the Recommended vitamin B12 Supply, and risks of deficiency increase in vegetarian and vegetalian populations [5]. Considering the importance of vitamin B12 intake for humans, the almost exclusive contribution of animal products to natural vitamin B12 supply and the regular decrease in red meat consumption in industrialised countries over the last twenty years, it would be of interest to introduce in the beef production systems practices that would maximise the vitamin B12 contents of ruminant meats.

The total body reserves in vitamin B12 is usually elevated, $60 \%$ of it being located in the liver and most of the rest being in muscles [6]. The whole body turnover of this vitamin is low and total depletion in vitamin B12 usually takes several years [3]. In this context, it is not known to what extent production factors may affect the vitamin B12 contents of ruminant tissues. The potential ruminal synthesis of this vita$\mathrm{min}$ is the first obvious factor of variation, which itself depends primarily on the dietary cobalt level [7]. In France, the geographical zones which are generally deficient in cobalt are known [8]. However, dietary supplementation of macro minerals generally has priority over that of trace minerals. Compliance with recommendations is respected with macro minerals, but no great attention is paid to individual trace elements unless specific deficiencies have already appeared in the herd. In any case, the objective of the supplementation is more to prevent deficiencies rather than to look for optimum trace mineral allowances. Differences in cobalt intake may thus be responsible for differences in the vitamin B12 contents of ruminant tissues. The nature of the diet has also been shown to influence the synthesis of the different chemical forms of vitamin B12 (active "true" and inactive forms) and therefore the tissue levels in vitamin B12 [9, 10]. This vitamin being hydrophilic and distributed differently among the cytosol and the mitochondria, it may be questioned whether different types of muscles may present different vitamin B12 contents. Finally, vitamin B12 has a role as a scavenger of free radicals $[11,12]$ and it may be questioned whether an increase of oxidative stress (such as that associated with increased physical activity at pasture) may affect the body reserves in vitamin B12.

Consequently, the present research project was aimed at determining the influence of the nature of the diet and of increased physical activity on the true vitamin B12 contents of different types of muscles and liver, in different ruminant species (bovines and ovines) which were raised according to usual French animal production systems.

Three studies were conducted to test the influence of the animal species (two studies on bovines and one study on ovines), of the nature of the diet (grass vs. maize silage, lucerne or concentrate based diets, representative of usual feeding conditions within each species) and of physical activity (with or without any significant walking distances, which may induce variable levels of oxidative stress, as in different production systems) on the vitamin B12 contents of plasma, two types of muscles and the liver. These studies were conducted on INRA experimental farms, where management practices are close to those applied on private farms.

\section{MATERIALS AND METHODS}

\subsection{Animals and treatments}

All experiments were conducted in the respect of the national legislation on animal care and on experimentation on living animals. 
Table I. Bovine studies No. 1 and 2: Ingredient composition of the diets and mineral supplementation, as measured in the last grazing season prior to slaughter.

\begin{tabular}{|c|c|c|c|c|c|}
\hline & \multicolumn{3}{|c|}{ Grass } & \multicolumn{2}{|c|}{ Maize silage } \\
\hline & Grazing & $\begin{array}{c}\text { Cut } \\
\text { without walking }\end{array}$ & $\begin{array}{c}\text { Cut } \\
\text { with walking }\end{array}$ & $\begin{array}{l}\text { Without } \\
\text { walking }\end{array}$ & $\begin{array}{c}\text { With } \\
\text { walking }\end{array}$ \\
\hline \multicolumn{6}{|l|}{ Bovine study No. 1} \\
\hline \multicolumn{6}{|l|}{$\begin{array}{l}\text { Ingredient composition } \\
\% \text { dry matter basis }\end{array}$} \\
\hline Perennial rye-grass & 100 & 100 & - & - & - \\
\hline Maize silage & - & - & - & 66 & - \\
\hline Wheat straw & - & - & - & 22 & - \\
\hline Rapeseed meal & - & - & - & 12 & - \\
\hline $\begin{array}{l}\text { Mineral supplementation, } \\
\mathrm{g} / \mathrm{d} / \text { animal }\end{array}$ & - & 100 & - & 100 & - \\
\hline \multicolumn{6}{|l|}{ Bovine study No. 2} \\
\hline \multicolumn{6}{|l|}{$\begin{array}{l}\text { Ingredient composition } \\
\% \text { dry matter basis }\end{array}$} \\
\hline Perennial rye-grass & 100 & 100 & 100 & - & - \\
\hline Maize silage & - & - & - & 68 & 68 \\
\hline Wheat straw & - & - & - & 23 & 23 \\
\hline Rapeseed meal & - & - & - & 9 & 9 \\
\hline $\begin{array}{l}\text { Mineral supplementation, } \\
\mathrm{g} / \mathrm{d} / \text { animal }\end{array}$ & - & 100 & 100 & 100 & 100 \\
\hline
\end{tabular}

* Not determined.

\subsubsection{Study No. 1: Comparison of grass and maize silage based diets on vitamin B12 contents of bovine tissues}

This study was conducted in Normandy on alluvial soils of no known cobalt deficiency. Twenty-four one-year-old Charolais steers, which had been castrated at nine months of age, were allotted into two treatment groups, 8 and 16 animals to Maize and Grass treatment groups, respectively, based on birth weight, weaning weight and body conformation. The whole study lasted 26 months, covering two winter seasons and two grazing seasons. The animals were housed in open sheds, with 8 animals per pen of $80 \mathrm{~m}^{2}$, except at pasture. The steers of the Maize group were fed maize silage (0.9 UFL, 50 PDIN and 70 PDIE) with a minimum amount of wheat straw (0.4 UFL, 22 PDIN and 44 PDIN) and rapeseed meal (1.1 UFL, 260 PDIN and 165 PDIE) during the whole duration of the experiment. Over the last grazing season, ingredient composition of the Maize diet averaged $66 \%$ maize silage, $22 \%$ wheat straw and $12 \%$ rapeseed meal respectively, on a dry basis (Tab. I). The feeding value of the ingredients and diets and the nutritional requirements of the animals were expressed, in this and subsequent experiments, according to the French INRA [13] Feeding Standards. The animals on the Grass treatment were 
fed during the winter seasons ad libitum grass silage (from a permanent pasture of perennial ryegrass, 0.85 UFL, 61 PDIN and 61 PDIE) with a minimum of hay and supplemented with a commercial concentrate (1.1 UFL, 11 PDIN and 128 PDIE). Over the last winter season, the grass silage, hay and concentrate contributed for 85,12 and $3 \%$ of the total dry matter intake. During the first grazing season, the animals on the Grass treatment were all on a rotative grazing of a perennial rye-grass pasture. For the second grazing season, the animals were split into two homogenous groups of 8 animals each, on the basis of their age and liveweight (Tab. I). The first group (Grazing Grass) was finished on a rotating grazing of a perennial rye-grass pasture $(0.85$ UFL, 88 PDIN and 86 PDIE), without any supplementation. The second group (Cut Grass) was offered fresh grass daily which had been cut from the same plot as that used by the Grazing Grass group.

No mineral supplementation was distributed at pasture, whereas all indoors feeding involved the distribution of a mineral supplement which contained $10 \mathrm{mg}$ cobalt $\cdot \mathrm{kg}^{-1}$. Individual animal allowance averaged $100 \mathrm{~g}$ of mineral supplement daily, corresponding to $1 \mathrm{mg}$ supplementary cobalt per animal and per day. This allowance was calculated on the basis of the recommended intake in phosphorus and calcium.

All animals were group fed. Feed intake of the grazing animals was estimated by determining the average grass height at the entry and exit of each plot as well as the average weight of grass cut over a $30 \mathrm{~m}^{2}$ area from each plot. Daily feed intake of indoor fed steers was determined by daily weighing of feed allowances and refusals. Live-weights were measured every two weeks. Feeding allowances of the Maize group were then adjusted every two weeks so that the animals fed on Maize would show the same average daily gain as those on Grass. The animals were then slaughtered at the end of the second grazing sea- son, at the same final age (30-32 months of age) and the same final average live-weight.

Just prior to slaughter, plasma samples were taken using EDTA as the anticoagulant after a night fast and stored at $-20^{\circ} \mathrm{C}$. At slaughter, liver and muscle (Rectus Abdominis, Semi Tendinosus) samples were taken and stored at $-80^{\circ} \mathrm{C}$. All plasma and tissue samples were then analysed for their contents in the active forms of vitamin B12. Representative feed samples were taken, dried $\left(80^{\circ} \mathrm{C}\right.$ for $48 \mathrm{~h}$ ), ground and pooled before being analysed for their cobalt content.

\subsubsection{Study No. 2: Comparison of grass and maize silage based diets and influence of physical activity on vitamin B12 contents of bovine tissues}

This study was also conducted in Normandy. Thirty Charolais steers were initially allotted to 2 groups according to the same principles as in study 1 (12 animals in a Maize group and 18 animals in a Grass group). Those animals were housed in open sheds with a maximum of 6 animals per pen of $40 \mathrm{~m}^{2}$ each. The animals on the Maize diet were fed over the whole duration of the experiment maize silage (0.9 UFL, 50 PDIN and 70 PDIE) ad libitum, with a minimum of wheat straw (0.4 UFL, 22 PDIN, 44 PDIE) and rapeseed meal (1.1 UFL, 260 PDIN, 165 PDIE). Over the last grazing season, the ingredient composition of the Maize diet averaged $68 \%$ maize silage, $23 \%$ wheat straw and $9 \%$ rapeseed meal respectively, on a dry basis (Tab. I). As for the animals on the Grass diet, they were fed in the winter seasons grass silage (0.85 UFL, 63 PDIN, 63 PDIE), with a minimum of wheat straw (0.4 UFL, 22 PDIN, 44 PDIE), urea (1610 PDIN) and rapeseed meal (1.1 UFL, 260 PDIN 165 PDIE). Over the last winter season, the ingredient composition of the "Grass" diet was $90 \%$ grass silage, $8 \%$ straw, $1 \%$ urea and $1 \%$ rapeseed meal. In the grazing seasons, they were fed freshly cut grass (0.9 UFL, 85 PDIN and 85 PDIE) alone. In the second grazing season, five groups of 
6 animals each were constituted (Tab. I). Two groups of animals on each diet were fed indoors, and for each diet one of the groups was submitted to a $5.2 \mathrm{~km}$ walk daily, which corresponded approximately to a 30 min walk before the morning meal plus a 30 min walk before the evening meal. The remaining 6 animals on Grass were grazing at pasture, on the same perennial rye-grass pasture as that used for the indoor animals. This resulted in 5 treatment groups : "Maize without forced walking", "Maize with forced walking", "Cut Grass without forced walking", "Cut Grass with forced walking" and "Grazing Grass".

Mineral supplementation, feeding and slaughter conditions, as well as sampling were similar to study No. 1.

\subsubsection{Study No. 3: Comparison of grass, dehydrated lucerne and concentrate based diets on the vitamin B12 contents of ovine tissues}

This last study was conducted in Auvergne, on granitic soils which are generally poor in cobalt [8]. Twenty-one INRA 401 lambs were blocked by live-weight and initial growth rate just after weaning at 11 weeks of age, and the animals within each block were allotted to one of three treatment groups "Grazing Grass", "Lucerne" and "Concentrate", with seven animals in each treatment group. The first group was conducted on grass pasture with their dam, on a rotative grazing of a permanent orchardgrass (Dactylis glomerata) based pasture. The availability of grass was never limiting and grass was always of good quality (at the vegetative stage). Licking blocks containing $90 \mathrm{mg}$ cobalt $\cdot \mathrm{kg}^{-1}$ were available on the pasture. The second group was fed indoors with dehydrated lucerne (0.84 UFL, 129 PDIN and 101 PDIE) and ad libitum wheat straw (0.58 UFL, 75 PDN and 82 PDIE). The third group was also fed indoors with a commercial concentrate (0.9 UFL, 110 PDIN and 105 PDIE) which contained $2 \mathrm{mg}$ cobalt $\mathrm{kg}^{-1}$ and with ad libitum wheat straw.
Indoor, the animals were fed individually. The intake of the pelleted feeds by the indoor fed lambs was determined by weighing the feed allowances and refusals twice weekly. Within each block, allowances of lucerne and concentrate were adjusted weekly so that empty live-weight gains would be similar to those of the lamb on the "Grazing Grass" treatment, live-weights being taken once a week. The animals were all slaughtered at 4.5 months of age at $35 \mathrm{~kg}$ live weight for the "Lucerne" and "Concentrate" treatments. The animals on the "Grazing Grass" treatment were slaughtered at $37 \mathrm{~kg}$ live-weight to account for differences in the weight of digestive contents. At slaughter, EDTA-plasma and muscle samples (Semi Tendinosus and Longissimus Dorsi) were taken and stored at $-80{ }^{\circ} \mathrm{C}$ to be analysed for their content in the active forms of vitamin B12. Representative feed samples were taken, dried $\left(80{ }^{\circ} \mathrm{C}\right.$ for $48 \mathrm{~h}$ ), ground and pooled before being analysed for their cobalt content.

\subsection{Chemical analyses}

Cobalt was analysed by electrothermy atomic absorption spectrometry after wetashing the samples in a micro-wave in the presence of nitric acid and hydrogen peroxyde.

Tissue samples were homogenised in an acetate buffer followed by hydrolysis with papaine in order to liberate the methyl and adenosyl- forms of vitamin B12, which are present in the cytoplasma and the mitochondria, respectively. The molecules thus liberated were then cyanised with sodium cyanide. Papaine activity was destroyed by autoclaving for $10 \mathrm{~min}$ at $121^{\circ} \mathrm{C}$. True vitamin B12 content was then quantified by radio-assay (BioRad kit Quantaphase II) which used the intrinsic factor (extracted from the swine stomacal mucosa) as the binding protein.

\subsection{Statistical analyses}

The results of studies No. 1 and 2 were analysed by analysis of variance according 
Table II. Bovine study No. 1: Influence of grass and maize silage based diets on true vitamin B12 concentrations in plasma, liver and Rectus Abdominis (RA) and Semi Tendinosus (ST) muscles. Concentrations in tissues are expressed on a wet weight basis. Daily total dry matter (DM) allowances and dietary cobalt contents are also indicated.

\begin{tabular}{|c|c|c|c|c|c|c|c|}
\hline & \multicolumn{2}{|c|}{ Grass } & \multirow{2}{*}{$\begin{array}{l}\text { Maize } \\
\text { silage }\end{array}$} & \multirow{2}{*}{ SEM } & \multirow{2}{*}{$P$ value } & \multirow{2}{*}{ Contrast $1^{\S}$} & \multirow{2}{*}{ Contrast $2^{\S}$} \\
\hline & Grazing & $\mathrm{Cut}$ & & & & & \\
\hline $\begin{array}{l}\text { DM allowances, } \\
\mathrm{kg} / \mathrm{d} / \mathrm{animal}\end{array}$ & 11.50 & 11.60 & 8.49 & & & & \\
\hline $\begin{array}{c}\text { Dietary cobalt, } \\
\mu \mathrm{g} \cdot \mathrm{kg}^{-1} \mathrm{DM}\end{array}$ & 346 & 436 & 166 & & & & \\
\hline Vitamin B12 concer & & & & & & & \\
\hline Plasma, $\mathrm{pg} \cdot \mathrm{mL}^{-1}$ & 158.3 & 112.1 & 160.2 & 19.85 & 0.18 & - & - \\
\hline Liver, ng. $\mathrm{g}^{-1}$ & 775.6 & 711.7 & 541.2 & 32.4 & 0.0001 & 0.0001 & - \\
\hline Muscle, $\mathrm{ng} \cdot \mathrm{g}^{-1}$ & & & & & & & \\
\hline$R A$ & 12.5 & 9.3 & 9.6 & 0.78 & 0.02 & 0.18 & 0.01 \\
\hline$S T$ & 5.7 & 4.9 & 5.8 & 0.87 & 0.74 & - & - \\
\hline
\end{tabular}

$\S$ Contrast 1: Grass (Grazing and Cut) vs. Maize, and Contrast 2: Grazing Grass vs. Cut Grass.

to a one-way factorial arrangement of treatments, with the treatment effect being the main factor. In the study No. 2, a second analysis of variance was applied excluding the treatment "Grass Grazing". The analysis was then conducted according to a twoway factorial arrangement of treatments. The model included as main effects the nature of the diet (grass vs. maize) as well as walking; the interaction was also tested. The results of study No. 3 were analysed according to a two-way factorial arrangement of treatments using blocks and treatments as the main effects. Treatment means were then compared by orthogonal contrasts. For study No. 1, contrasts were C1: Maize vs. Grass, C2: Cut Grass vs. Grazing Grass. For study No. 2, contrasts were C1: Maize (with or without walking) vs. Grass (cut, with or without walking, or grazing), C2: Maize (with or without walking) vs. Cut Grass (with or without walking), C3: Without walking (Cut Grass or Maize) vs. with walking (Cut Grass or Maize), and C4: Grazing Grass vs. Cut Grass (with or without walking). Contrasts for study No. 3 were C1: Grazing Grass vs. Indoors (Lucerne or Concentrate) and C2: Lucerne vs. Concentrate. The treatment means are reported as well as the residual standard error of the treatment means (SEM $=\sqrt{(\text { residual mean square } / \text { number }}$ of observations by treatment)). All statistical analyses were conducted using the GLM procedure of SAS [14].

\section{RESULTS}

\subsection{Study No. 1: Comparison of grass and maize silage based diets on vitamin B12 contents of bovine tissues}

During the second grazing season (prior to slaughter), total dry matter allowances averaged $11.50,11.60$ and $8.49 \mathrm{~kg}$ per animal and per day for the Grazing Grass, Cut Grass and Maize treatments, respectively, including the mineral supplement for the last two treatments (Tab. II). Considering the cobalt content of feeds which amounted to 51,349 and $125 \mu \mathrm{g} \cdot \mathrm{kg}^{-1} \mathrm{DM}$ for the 
maize silage, the fresh (cut or grazed) grass and the rapeseed meal respectively, daily cobalt allowances differed widely among treatments. It averaged 4014, 5014 and $1416 \mu \mathrm{g}$ cobalt per animal and per day during that period, for the Grazing Grass, Cut Grass and Maize treatments respectively. The cobalt content of the total ration averaged 346, 436 and $166 \mu \mathrm{g} \cdot \mathrm{kg}^{-1} \mathrm{DM}$ in the same respective order (Tab. II). During the previous winter season, the cobalt content of the whole diet was similar for the maize diet, but 1.6 to 1.3 fold higher for the two other treatments as a consequence of a high cobalt content in the grass silage $\left(530 \mu \mathrm{g} \cdot \mathrm{kg}^{-1} \mathrm{DM}\right)$, and of the fact that the animals of the Grazing Grass treatment received a mineral supplement during the winter season.

Growth performance was similar across treatment groups, as planned. The daily live-weight gains over the whole experimental period averaged 771 (SD 70), 770 (SD 59) and 782 (SD 96) $\mathrm{g}$ for the Grazing Grass, Cut Grass and Maize treatment groups, respectively. Final live-weights at slaughter averaged 775 (SD 37), 780 (SD 58) and 791 (SD 90) kg, in the same respective order, without any significant differences across treatment groups.

Despite large differences in cobalt allowances, plasma concentrations in true vita$\min \mathrm{B} 12$ averaged $143.5 \mathrm{pg} \cdot \mathrm{mL}^{-1}$ and were not significantly modified by the treatments (Tab. II).

In the hepatic tissue, true vitamin B12 concentrations were high $\left(676 \mathrm{ng} \cdot \mathrm{g}^{-1}\right.$ on average) and were significantly affected by the treatments (Tab. II). The concentrations were $37 \%$ higher with the two Grass treatments as compared with the Maize treatment $(P<0.0001)$. Grazing per se had no significant effect.

In muscles, true vitamin B12 concentrations were approximately twice higher in the Rectus Abdominis (10.5 ng. $\mathrm{g}^{-1}$ ) than in the Semi Tendinosus (5.5 $\mathrm{ng} \cdot \mathrm{g}^{-1}$ ) (Tab. II). A significant treatment effect was noted for the Rectus Abdominis only which presented
$34 \%$ higher values with the Grazing Grass treatment as compared with the Cut Grass treatment $(P<0.02)$.

\subsection{Study No. 2: A comparison of grass and maize silage based diets and influence of physical activity on vitamin B12 contents of bovine tissues}

Total DM allowances averaged 12.31, $12.00,9.37$ and $9.25 \mathrm{~kg}$ per animal and per day during the second grazing season (mineral supplement included) for the Cut Grass without and with Forced Walking, Maize without and with Forced Walking treatments respectively (Tab. III). For practical reasons, feed intake of the grazing animals could not be estimated. Daily cobalt allowances were calculated to average 4284 , 4201, 1203 and $1202 \mu \mathrm{g}$ per animal in the same respective order, based on the measured cobalt contents of 15,269 and $125 \mu \mathrm{g} \cdot \mathrm{kg}^{-1}$ DM for the maize silage, fresh (cut or grazed) grass and rape-seed meal and on the supplemented cobalt. The cobalt content of the total dietary DM thus averaged 269, $348,350,128$ and $130 \mu \mathrm{g}$ cobalt $\cdot \mathrm{kg}^{-1} \mathrm{DM}$ for the Grazing Grass, Cut Grass without and with Forced Walking, Maize without and with Forced Walking treatments respectively (Tab. III). Similar dietary cobalt contents had been calculated for the second winter season.

As for study No. 1 and as planned, growth performances were similar across treatments. The average daily gains over the whole experimental period were 769 (SD 68), 815 (SD 50), 775 (SD 22), 801 (SD 55) and 793 (SD 47) g for the Grazing Grass, Cut Grass without and with Forced walking, Maize without and with Forced walking treatment groups, respectively. Final liveweights at slaughter averaged 773 (SD 70), 823 (SD 40), 790 (SD 22) and 809 (SD 44), 807 (SD 38) kg, in the same respective order, without any significant differences across treatment groups. 
Table III. Bovine study No. 2: Influence of grass and maize silage based diets as well as physical activity on true vitamin B12 concentrations in plasma, liver and Rectus Abdominis (RA) and Semi Tendinosus (ST) muscles. Concentrations in tissues are expressed on a wet weight basis. Daily total dry matter (DM) allowances and dietary cobalt contents are also indicated.

\begin{tabular}{|c|c|c|c|c|c|c|c|c|}
\hline & \multicolumn{3}{|c|}{ Grass } & \multicolumn{2}{|c|}{ Maize } & \multirow[t]{2}{*}{ SEM } & \multirow[t]{2}{*}{$P$ value } & \multirow[t]{2}{*}{ Contrasts } \\
\hline & Grazing & $\begin{array}{l}\text { Without } \\
\text { walking }\end{array}$ & $\begin{array}{c}\text { With } \\
\text { walking }\end{array}$ & $\begin{array}{l}\text { Without } \\
\text { walking }\end{array}$ & $\begin{array}{c}\text { With } \\
\text { walking }\end{array}$ & & & \\
\hline $\begin{array}{l}\text { DM allowances, } \\
\mathrm{kg} / \mathrm{d} / \mathrm{animal}\end{array}$ & ND* & 12.31 & 12.00 & 9.37 & 9.25 & & & \\
\hline $\begin{array}{c}\text { Dietary cobalt, } \\
\mu \mathrm{g} \cdot \mathrm{kg}^{-1} \mathrm{DM}\end{array}$ & 269 & 348 & 350 & 128 & 130 & & & \\
\hline Vitamin B12 concer & ntrations & & & & & & & \\
\hline Plasma, pg.mL $\mathrm{mL}^{-1}$ & 155.3 & 124.0 & 129.4 & 102.5 & 171.0 & 29.07 & 0.50 & - \\
\hline $\begin{array}{l}\text { Liver, } \mathrm{ng}^{-\mathrm{g}^{-1}} \\
\text { Muscle, } \mathrm{ng} \cdot \mathrm{g}^{-1}\end{array}$ & 699.8 & 782.1 & 729.1 & 509.8 & 498.7 & 56.51 & 0.01 & $\mathrm{C} 1: P<0.001$ \\
\hline$R A$ & 11.2 & 11.7 & 11.2 & 11.8 & 9.1 & 0.67 & 0.07 & - \\
\hline$S T$ & 4.2 & 5.8 & 5.8 & 3.9 & 3.6 & 0.84 & 0.23 & - \\
\hline
\end{tabular}

* ND: not determined.

Plasma concentrations of true vitamin B12 amounted to levels similar to those noted in study No. 1 . They averaged $136 \mathrm{pg} \cdot \mathrm{mL}^{-1}$ and did not show any significant differences among treatments, despite differences in cobalt intake (Tab. III).

Hepatic concentrations in true vitamin B12 were also similar to those found previously (644 ng. ${ }^{-1}$ on average, Tab. III). In this study, grass based diets also increased hepatic concentrations, by $46 \%$, relative to maize based diets $(P<0.01)$. On the contrary, management practices (grazing or walking) had no significant effects.

In muscles, true vitamin B12 concentrations were approximately twice higher in the Rectus Abdominis as compared with those in the Semi Tendinosus (11 vs. $4.47 \mathrm{ng} \cdot \mathrm{g}^{-1}$ respectively). For a given type of muscle, no significant effects of treatments could be detected.

The second factorial analysis which excluded the Grass Grazing group confirmed previous statistical results obtained on plasma and hepatic tissue (results not shown). It allowed to better dissociate the effects of the diets (Maize vs. Grass) from those of exercise (with or without walking). However these effects were not systematic for both muscles. This analysis indicated that in the Semi Tendinosus a Cut Grass based diet resulted in 56\% higher vitamin B12 levels $(P<0.04)$ as compared to a Maize based diet. Finally, in the Rectus Abdominis a significant 14\% decrease in true vitamin B12 concentrations was detected as a result of forced walking $(P<0.03)$.

\subsection{Study No. 3: A comparison of grass, dehydrated lucerne and concentrate based diets on vitamin B12 contents of ovine tissues}

Total DM intake of lambs averaged 747 and $705 \mathrm{~g}$ per animal and per day for the Lucerne and Concentrate treatments respectively (Tab. IV). Daily live-weight gains were higher for the lambs fed on Grass $\left(208 \pm 36.0 \mathrm{~g} \cdot \mathrm{d}^{-1}\right)$ than for those fed 
Table IV. Ovine study No. 3: Influence of grass, dehydrated lucerne and concentrate based diets on true vitamin B12 concentrations in plasma, and Longissimus Dorsi $(L D)$ and Semi Tendinosus (ST) muscles. Concentrations in tissues are expressed on a wet weight basis. Daily total dry matter (DM) allowances and the dietary cobalt contents are also indicated.

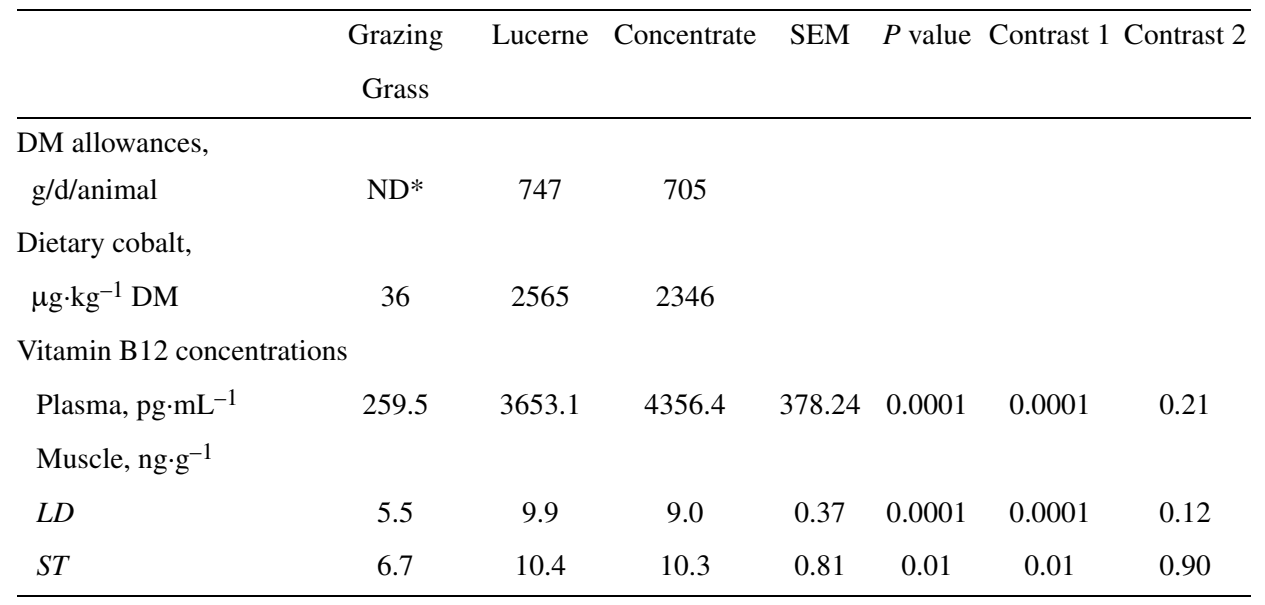

Contrast 1: Grazing Grass vs. lucerne, concentrate, Contrast 2: lucerne vs. concentrate.

* ND: not determined.

on Lucerne $\left(144 \pm 18.4 \mathrm{~g} \cdot \mathrm{d}^{-1}\right)$ or Concentrate $\left(147 \pm 35.8 \mathrm{~g} \cdot \mathrm{d}^{-1}\right)$. As planned, final live-weight at slaughter was also higher for the Grass fed animals $(37.7 \pm 3.00$ vs. $34.0 \pm$ 2.21 and $35.3 \pm 1.53$, in the same respective order).

Cobalt content of the feeds averaged $36 \mu \mathrm{g} \cdot \mathrm{kg}^{-1} \mathrm{DM}$ for the grazed grass, 2565 and $2346 \mu \mathrm{g} \cdot \mathrm{kg}^{-1} \mathrm{DM}$ for the Lucerne and Concentrate, respectively (Tab. IV). Cobalt intake could only be calculated for the indoor fed animals. It averaged 1916 and $1654 \mu \mathrm{g}$ per animal and per day on the Lucerne and Concentrate treatments respectively.

Plasma concentrations in true vitamin B12 (Tab. IV) averaged $260 \mathrm{pg} \cdot \mathrm{mL}^{-1}$ in lambs fed at pasture, but were significantly higher in lambs fed indoors with either Lucerne or Concentrate $\left(4005 \mathrm{pg} \cdot \mathrm{mL}^{-1}\right.$, $P<0.0001)$. The concentrations were similar between muscles (Tab. IV), $9.1 \mathrm{ng} \cdot \mathrm{g}^{-1}$ for the Semi Tendinosus and $8.1 \mathrm{ng} \cdot \mathrm{g}^{-1}$ for the Longissimus Dorsi. For both muscles, the animals on the grazing treatment showed 35 to $42 \%$ lower concentrations than the animals fed indoors $(P<0.01)$.

\section{DISCUSSION}

Considering that cobalt is the obligatory precursor of vitamin B12 synthesis in the rumen and that cobalt intake is determinant for the vitamin B12 status of the animal, it is thus necessary to first comment on the cobalt allowances of the animals before discussing the specific effects of the treatments on tissue true vitamin B12 levels.

\subsection{Cobalt allowances and tissue vitamin B12 concentrations}

As aforementioned, the cobalt allowances had not been equalised across experimental treatments. On the contrary, cobalt allowances had been intentionally set by the usual on-farm practices of mineral supplementation applied to the meat stock in France. In practice, when animals are fed indoor with 
forage or on-farm produced feeds, mineral supplementation is considered as a whole, thanks to the use of preset mixtures of macro plus trace minerals and vitamins. Supplement allowances are then dictated in priority by the requirements and supply of major minerals such as calcium and phosphorus. When animals are grazing, minerals may be supplemented as licking blocks. In both cases, little attention is paid to the optimum supply of each individual trace mineral within the whole diet. The objective is then to provide minimum levels of minerals to theoretically avoid any risk of deficiency. Feed manufacturers, however, design concentrates that are usually enriched in most minerals. The present experimental choice of not controlling a priori the cobalt allowances was made in order to evaluate the impact of the usual different management and feeding practices on vitamin B12 content in meat.

In the present experiments, the range of cobalt content in the total rations was wide, varying from 1 to 3.4 fold in the bovine studies and from 1 to 70 fold in the ovine study. Despite this variability, the cobalt allowances complied with the levels usually recommended to avoid deficiencies $(110 \mu \mathrm{g}$ cobalt $\left.\cdot \mathrm{kg}^{-1} \mathrm{DM},[15]\right)$ in all treatments except for the Grass Grazing lambs in study No. 3. For that treatment, cobalt allowances were $67 \%$ below the deficiency threshold. However if the higher and more recent cobalt allowances are considered, such as those determined by Stangl et al. [16] in growing cattle $\left(250 \mu \mathrm{g}\right.$ cobalt $\left.\mathrm{kg}^{-1} \mathrm{DM}\right)$, then the Maize diets would also be cobalt deficient in studies 1 and 2 .

Two indicators are generally used to determine the cobalt status of the animals. First, the plasma vitamin B12 concentrations, which are modified by the short term changes in vitamin B12 absorption and second the level of the body stores in vitamin B 12 which are located for $60 \%$ in the liver $[2,17]$. These two indicators are poorly correlated $[17,18]$ and are therefore complementary to each other.
In the bovines, no obvious cobalt deficiency was apparent from the combination of the two indicators. Indeed all measured hepatic levels in true vitamin B12 were above deficiency thresholds (200 $\mathrm{ng} \cdot \mathrm{g}^{-1}$ [15] or $350 \mathrm{ng} \cdot \mathrm{g}^{-1}$ in steers, [16]) even for the Maize treatments. Plasma vitamin B12 concentrations (varying between 103 and $158 \mathrm{pg} \cdot \mathrm{mL}^{-1}$ ) were, for all treatments, surprisingly below the theoretical thresholds of cobalt deficiency $\left(200 \mathrm{pg} \cdot \mathrm{mL}^{-1}\right.$, [15]) or even below the threshold determined experimentally in one year old steers fed a cobalt deficient diet (295 $\mathrm{pg} \cdot \mathrm{mL}^{-1}$ ) [16] probably because of blood sampling being carried out after an overnight fast. Also, no relationship was noted between plasma vitamin B12 concentrations and dietary cobalt allowances on the contrary to recent findings by Stangl et al. [16] and Tiffany et al. [19]. No clear explanation can be given for these contradictory results. Thus, in the present experiments the two indicators did not converge, suggesting that vitamin B12 stores were probably sufficient to compensate for any low levels of vitamin B12 absorption. No cobalt deficiency can thus be clearly suspected in the bovines.

In the ovines (study No. 3), however, differences in cobalt status could be suspected even though hepatic concentrations in vitamin B12 were unfortunately not available. Indeed, in lambs fed Lucerne or Concentrate, plasma levels were extremely high. They were similar to those measured in ewes fed a mixed diet containing grass silage and a limited amount of concentrate [20] and higher than those measured in pasture-fed, cobalt-supplemented lambs [21]. These high levels are compatible with known species differences in cobalt non-deficient ruminants, with much higher serum levels in ovines than in bovines [7]. They clearly suggest that on those two treatments cobalt allowances were not limiting. However, Grass Grazing lambs showed plasma vitamin B12 levels which were only slightly above the deficiency threshold (259 vs. $200 \mathrm{pg} \cdot \mathrm{mL}^{-1}$ ) [15]. For that treatment, the grass was cobalt deficient. Free access to a 


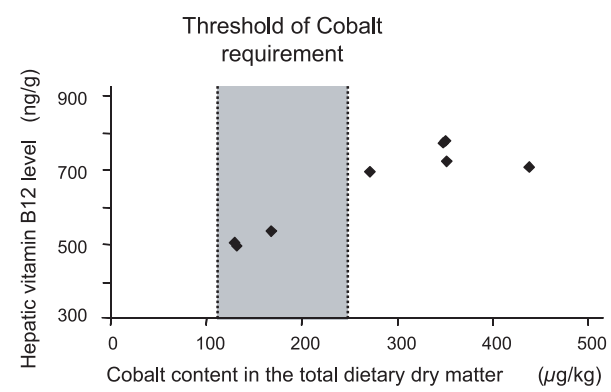

Figure 1. The influence of the average cobalt content in the total dietary dry matter on mean hepatic true vitamin B12 level (expressed on a wet weight basis) in bovines. Thresholds of cobalt requirements defined either as $110 \mu \mathrm{g}$ Co $\cdot \mathrm{kg}^{-1} \mathrm{DM}$ by Underwood [14] or as $250 \mu \mathrm{g}$ $\mathrm{Co} \cdot \mathrm{kg}^{-1} \mathrm{DM}$ by Stangl et al. [15] are indicated.

mineral licking block was provided, however no observations were made as to whether the lambs used the licking block. Present plasma results suggest a limited intake of supplementary cobalt, leading to a cobalt status which may be borderline with (sub-) deficiency.

Hepatic vitamin B12 levels are known to respond quadratically to dietary cobalt [16]. Indeed in growing cattle, hepatic levels increased with cobalt intake up to a plateau once dietary cobalt reached $205-236 \mu \mathrm{g} \cdot \mathrm{kg}^{-1}$ DM; this broken point was considered to indicate the cobalt requirement [16]. In the present bovine studies, vitamin B12 content in the liver clearly increased with the cobalt level in the whole diets (Fig. 1), across treatments. Dispersion of data was inadequate to attempt establishing linear or curvilinear responses. However, data strongly indicate that when dietary Co content was between the lower [15] and the upper [16] thresholds of requirements, hepatic vitamin B12 levels were approximately one third lower than when dietary Co content was above those thresholds (Fig. 1). These effects are coherent with the fact that hepatic stores constitute the main body reserve in vitamin B12. On the contrary, vitamin B12 concentra-

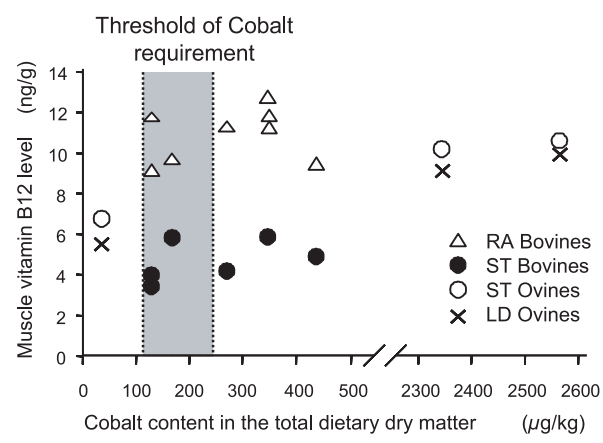

Figure 2. The influence of the average cobalt content in the total dietary dry matter on mean muscular true vitamin B12 level (expressed on a wet weight basis) in bovines and ovines. Thresholds of cobalt requirements defined either as $110 \mu \mathrm{g} \mathrm{Co} \cdot \mathrm{kg}^{-1} \mathrm{DM}$ by Underwood [14] or as $250 \mu \mathrm{g} \mathrm{Co} \cdot \mathrm{kg}^{-1} \mathrm{DM}$ by Stangl et al. [15] are indicated. The abbreviations $R A, S T$ and $L D$ stand for Rectus Abdominis, Semi Tendinosus and Longissimus Dorsi, respectively.

tions in the muscle were not clearly and systematically affected by the dietary treatments in bovines (Fig. 2). In ovines, vitamin B12 levels in muscles were significantly reduced in the Grazing animals which also presented the lowest cobalt allowances. Consequently, it seems that when cobalt allowances are (sub-)deficient, hepatic vitamin B12 levels are reduced and when those allowances are even lower, muscle vitamin B12 levels may also be reduced. The extent of vitamin B12 storage in muscles might be affected after a given level of hepatic depletion. The latter threshold would remain to be determined.

The present results on cobalt allowances and tissue vitamin B12 concentrations demonstrate that in practice cobalt allowances varied extremely widely from (sub-)deficient to plethoric amounts. Recommendations in trace mineral allowances are not correctly followed by producers and feed manufacturers. In addition, the discussion on threshold levels suggests that the recommendations for optimum cobalt requirements would probably need to be up-dated and that the possible 
influence of cobalt allowances on hepatic and muscular vitamin B12 levels should be clarified.

\subsection{Treatment effects on tissue vitamin B12 concentrations}

As for nutritional treatments, in the bovine studies, hepatic vitamin B12 levels were significantly higher with Grass based diets as compared with Maize based diets. In muscles, a similar dietary effect was noted in the ST only (study No. 2 only). No dietary differences were noted in RA. These treatment effects are clearly biased by differences in cobalt allowances as discussed above. It was not possible to decide whether the treatment effects were due to differences in cobalt intake or to forage effects. Indeed, the present results were also coherent with the known increase in ruminal microbial synthesis of true vitamin B12 with the proportion of forage in the diet $[9$, $10,22]$. However, the ruminal fermentation profiles of the two types of diet were probably not sufficiently different $[13,23]$ to induce different hepatic requirements in vitamin B12 [7]. In the ovines, the only significant treatment difference (Grass vs. Lucerne and Concentrate) was associated to differences in cobalt intake.

As for the influence of physical activity, it had been assumed that any oxidative stress applied to the animals, such as an increase in physical activity, could increase vitamin $\mathrm{B} 12$ requirements at the tissue level, especially in the muscle. The duration of the controlled physical activity applied here ( $1 \mathrm{~h}$ of forced walking daily) was chosen on the basis of the measured increment of time grazing animals (on a rotative grazing) spent walking as compared with indoor fed ones (D. Dozias, unpublished observations). The present results showed a significant effect of exercise in only one muscle, and the extent of this effect was limited. It is thus likely that the intensity of walking applied here was insufficient in itself to induce an oxidative stress which would reduce tissue vitamin B12 stores.
As a conclusion, the treatments applied which represented different management practices of beef cattle and growing lambs significantly affected hepatic, and to a very limited extent muscular, vitamin B12 levels, but those treatment effects seemed essentially related to variations in cobalt allowances.

\subsection{Muscle differences in tissue vitamin B12 concentrations}

One interesting and original outcome from these results is the clear impact of the type of muscle on true vitamin B12 levels. In the present work, the muscles to be sampled were selected on the basis of their metabolic characteristics and of their interest in retail. In bovines, the Rectus Abdominis is an oxidative type muscle and it showed concentrations which were double (10.8 vs. $5.0 \mathrm{ng} \cdot \mathrm{g}^{-1}$ ) those of the Semi Tendinosus which is a glycolytic type muscle [24]. In ovines, the Longissimus Dorsi and the Semi Tendinosus are both mixed type muscles, the Longissimus Dorsi being slightly more oxidative than the Semi Tendinosus [25]. Concentrations in those oxido-glycolytic muscles in non-Co-deficient lambs were close to those measured for the more glycolytic muscle in bovines. Large differences in muscle metabolism, such as those noted between the $R A$ and $S T$ in bovines, are probably required to induce large differences in vitamin B12 contents. To our knowledge, such differences have not been previously reported.

A known structural difference between oxidative and glycolytic type muscle fibres is their content in the mitochondria, which is more elevated in oxidative fibres [26]. The adenosyl form of vitamin B12, which in humans is the major cellular form, is preferentially located in the mitochondria, being associated to methylmalonyl-CoA-mutase, while the methyl form of vitamin B12 is located in the cytosol in association with methionine synthase [3, 27-29]. Differences in vitamin B12 contents between the different types of muscles might thus be 
attributed to the adenosyl form in the mitochondria. This coenzyme is active in the metabolic pathways for the catabolism of some branched amino acids. Those differences would be coherent with the fact that protein turnover, and thus amino acid catabolism, is higher in oxidative type muscles than in more glycolytic ones [30]. Another hypothesis may simply relate to the higher vascularisation of oxidative fibres [26] which would favour substrate supply, uptake and storage.

It is now well known that muscle characteristics are modified by numerous management factors (breed, sex, age, growth path, nature of the diet, ...) [26]. It would be interesting to determine to what extent vitamin B12 content in the muscle could also be modified.

\subsection{Average concentrations in tissue vitamin B12}

A last striking observation is that the true vitamin B12 contents of muscles, whether they are measured in bovines or in ovines ( 0.5 to $1 \mu \mathrm{g} \cdot 100 \mathrm{~g}^{-1}$ fresh raw muscle tissue) are generally lower than the values published previously for miscellaneous raw beef or bison muscle (ranging from 1.3 to $2.7 \mu \mathrm{g} \cdot 100 \mathrm{~g}^{-1}$ ) [31-33] and clearly lower, by 2 to 6 fold, than the levels reported in the Tables of Feed Composition for Humans ( 2 to $3 \mu \mathrm{g} \cdot 100 \mathrm{~g}^{-1}$ of cooked meat) [34]. No clear explanation is presently available. From the present results, it is obvious that the variability of vitamin B12 content between the muscles should be more fully explored. The impact of cooking on tissue vitamin B12 levels is also clearly possible. From previous reports, cooking was shown to increase tissue vitamin B12 content when expressed on an as is basis, as a result of water and fat loss from the meat sample [35]. However, the effect of cooking on the variability of tissue vitamin B12 content is not known.

The impact of methodological differences on the observed discrepancies should also be considered. The specificity of the analytical methods used to determine tissue vitamin B12 levels (whether they detect the biologically active forms only or also the inactive ones) may be involved. However, in body tissues, active forms of vitamin B12 are predominant. Indeed, vitamin B12 is transported in the cells by transporters which are specific to the biologically active forms [36]. Walker and Elliott [9] reported that the inactive forms of vitamin B12 were not significantly detected in hepatic cells nor in milk. In the present studies, preliminary tests confirmed that the inactive forms represented only $3 \%$ of total vitamin B12 in ovine muscles (unpublished observations). Such would not be the case in blood [10]. Differences in accuracy and fidelity among methods are likely to be involved in the above mentioned discrepancies, even though they are difficult to compare. In any case, this aspect requires to be clarified because of its possible impact on human nutrition.

\subsection{Implications}

On the basis of the present results, it may be calculated that the consumption of a raw liver portion of $100 \mathrm{~g}$ would cover approximately 30 fold the recommended intake in vitamin B12 for humans (which averages $2.4 \mu \mathrm{g} \cdot \mathrm{d}^{-1}$ ) [37]. By contrast, $100 \mathrm{~g}$ of raw meat would supply 46 to $20 \%$ of the recommended intake depending on whether the meat would come from an oxidative or glycolytic type muscle. Considering the impact of cobalt intake on liver values and the range of variation measured within muscle tissues, it would be worth investigating the influence of production factors on vitamin B12 levels in meat.

\section{ACKNOWLEDGEMENTS}

The authors gratefully acknowledge the expert contribution of the staff of the two INRA experimental stations (Le Pin-au-Haras and Intrabois, Theix) for running the experiments, of the INRA Theix Slaughter House for slaughtering the animals, of Agnès Thomas for tissue sampling, of Caroline Roy and Chrystiane 
Plante for the vitamin B12 analyses, and of Y. Anglaret for the statistical analyses. The financial support from the Fonds National d'Aménagement et de Développement du Territoire is gratefully acknowledged.

\section{REFERENCES}

[1] Geay Y, Bauchart D, Hocquette JF, Culioli J Effect of nutritional factors on biochemical, structural and metabolic characteristics of muscles in ruminants, consequences on dietetic value and sensorial qualities of meat. Reprod Nutr Dev 2001, 41:1-26.

[2] McDowell LR. Vitamins in Animal and Human Nutrition, 2nd ed, Iowa State University Press, Ames, Iowa, USA, 2000.

[3] Le Grusse J, Watier B. Les Vitamines, Données Biochimiques, Nutritionnelles et Cliniques. CEIV, 1993, p 255-271.

[4] Scott JM. Bioavailability of vitamin B12. Eur J Clin Nutr 1997, 51 (Suppl 1): S49-S53.

[5] Krajcovicova-Kudlackova M, Blazicek P, Babinska K, Kopcova J, Klvanova J, Bederova A, Magalova T. Traditional and alternative nutrition-levels of homocysteine and lipid parameters in adults. Scand J Clin Lab Invest 2000, 60: 657-664.

[6] Combs GF Jr. The Vitamins. Fundamental Aspects in Nutrition and health, 2nd ed, Academic Press, San Diego, California, USA, 1998.

[7] Elliott JM. Propionate metabolism and vitamin B12. In: Ruckebusch Y, Thivend P (Eds), Digestive Physiology and Metabolism in Ruminants, Avi Publishing Co, Inc, Westport, CO, USA, 1980, p 485-503.

[8] Tressol JC. Le dosage du cobalt : la carence en cobalt en France, cinétique d'apparition et traitement de la carence chez le mouton. Diplôme d'Études Supérieures de l'Université de Clermont II, 1978.

[9] Walker CK, Elliott JM. Lactational trends in vitamin B12 status on conventional and restricted-roughage rations. J Dairy Sci 1972, 55: 474-479.

[10] Halpin CG, Harris DJ, Caple IW. Contribution of cobalamin analogues to plasma vitamin B12 concentrations in cattle. Res Vet Sci 1984, 37: 249-251.

[11] Douglas JS, Morrow FD, Ono K, Keeton JT, Vanderslice JT, Post RC, Winis BW. Impact of sodium ascorbate and sodium erythorbate used in meat processing on the vitamin B12 contents of cured ham. J Food Sci 1989, 54: 1473-1474.

[12] Hermann W, Schorr H, Purschwitz K, Rassoul F, Richter V. Total homocysteine, vitamin $B_{12}$, and total antioxidant status in vegetarians. Clin Chem 2001, 47: 1094-1101.

[13] Institut National de la Recherche Agronomique. Alimentation des Ruminants. INRA Publications, Versailles, 1978.

[14] SAS. SAS/STAT User's Guide, Version 6, 4th ed, SAS Institute Inc, Cary, NC, USA, 1990.

[15] Underwood EJ. The Mineral Nutrition of Livestock. Commonwealth Agricultural Bureaux, Slough, UK, 1981.

[16] Stangl GI, Schwarz FJ, Müller H, Kirchgessner M. Evaluation of the cobalt requirement of beef cattle based on vitamin B12, folate, homocysteine and methylmalonic acid. $\mathrm{Br} \mathrm{J}$ Nutr 2000, 84: 645-653.

[17] Kawashima T, Henry PR, Ammerman CB, Littell RC, Price J. Bioavailability of cobalt sources for ruminants. 2. Estimation of the relative value of reagent grade and feed grade cobalt sources from tissue cobalt accumulation and vitamin B12 concentrations. Nutr Res 1997, 17: 957-974.

[18] Millar KR, Penrose ME. A comparison of Vitamin B12 levels in the livers and sera of sheep measured by microbiological and radioassays methods. N Z Vet J 1980, 28: 97-99.

[19] Tiffany ME, Spears W, Xi L, Horton J. Influence of dietary cobalt source and concentration on performance, vitamin $\mathrm{B}_{12}$ status, and ruminal and plasma metabolites in growing and finishing steers. J Anim Sci 2003, 81: 3151-3159.

[20] Girard CL, Castonguay F, Matte JJ. Response of serum concentrations of folates to dietary supplements of folic acid given to ewes during gestation. Can J Anim Sci 1999, 79: 387-389.

[21] Vellema P, Moll L, Barkema HW, Schukken YH. Effect of cobalt supplementation of serum vitamin $B_{12}$ levels, weight gain and survival rate in lambs grazing cobalt-deficient pastures. Vet Q. 1997, 19: 1-5.

[22] Sutton AL, Elliott JM. Effect of ratio of roughage to concentrate and level of feed intake on ovine ruminal vitamin B12 production. J Nutr 1972, 102: 1341-1346.

[23] Majdoub L, Vermorel M, Ortigues-Marty I. Intraruminal propionate supplementation modifies hindlimb metabolism without changing the net splanchnic release of glucose in growing lambs. Br J Nutr 2003, 89: 39-50. 
[24] Jurie C, Bauchart D, Listrat A, Picard B, Giraud X, Dozias D, Jailler R, Geay Y, Hocquette JF. Influence du rythme de croissance et de la nature de l'alimentation sur les caractéristiques musculaires de bœufs Charolais de 20 mois. Viande Prod Carnés 2000, Hors Série: 59-64.

[25] Briand M, Talmant A, Briand Y, Monin G, Durand R. Metabolic types of muscle in the sheep: I. Myosin ATPase, glycolytic, and mitochondrial enzyme activities. Eur J Appl Physiol 1981, 46: 347-358.

[26] Hocquette JF, Ortigues-Marty I, Pethick D, Herpin P, Fernandez X. Nutritional and hormonal regulation of energy metabolism in skeletal muscles of meat-producing animals. Livest Prod Sci 1998, 56: 115-143.

[27] Kolhouse JF, Allen RH. Recognition of two intracellular cobalamin binding proteins and their identification as methylmalonyl-CoA mutase and methionine synthetase. Proc Natl Acad Sci USA 1977, 74: 921-925.

[28] Mellman IS, Youngdahl-Turner P, Willard $\mathrm{HF}$, Rosenberg LE. Intracellular binding of radioactive hydroxocabalamin to cobalamindependent apoenzymes in rat liver. Proc Natl Acad Sci USA 1977, 74: 916-920.

[29] Bender DA. Nutritional Biochemistry of the Vitamins. Cambridge University Press, Cambridge, 1992.

[30] Garlick PJ, Maltin CA, Baillie AGS, Delday MI, Grubb DA. Fiber-type composition of nine rat muscles. II. Relationship to protein turnover. Am J Physiol 1989, 257: E828E832.

[31] Driskell JA, Yuan X, Giraud DW, Hadley M, Marchello MJ. Concentrations of selected vitamins and selenium in bison cuts. J Anim Sci 1997, 75: 2950-2954.

[32] Watanabe F, Takenaka S, Abe K, Tamura Y, Nakano Y. Comparison of a microbiological assay and a fully automated chemiluminescent system for the determination of vitamin B12 in food. J Agric Food Chem 1998, 46: 1433 1436.

[33] Indyk HE, Persson BS, Caselunghe MCB, Moberg A, Filonzi EL, Woollard DC. Determination of vitamin B12 in milk products and selected foods by optical biosensor proteinbinding assay: method comparison. J AOAC International 2002, 85: 72-81.

[34] Favier JC, Ireland-Ripert J, Toque C, Feinberg M. Répertoire Général des Aliments, Table de Composition. INRA ed, Paris, 1995.

[35] Bennink MR, Ono K. Vitamin B12, E and D content of raw and cooked beef. J Food Sci 1982, 47: 1786-1792.

[36] Markle HV. Cobalamin. Clin Lab Sci 1996, 33: 247-356.

[37] Guéant JL, Namour F, Aimone-Gastin I, Nicolas JP. Vitamine B12 (cobalamines). In: Apports conseillés pour la population française. Éditions Tec \& Doc, Londres, Paris, New York, 2001, p 211-215. 